\title{
Penerapan Pendekatan Keterampilan Proses dalam PEMBElajaran MATEMATIKA TERHADAP KEMAMPUAN PEMECAHAN MASALAH PADA PESERTA DIDIK KELAS VIII SMP DDI SIBATUA PANGKAJENE
}

\author{
The APPlication of Process SKILl APPROaCh in MATHEMATICAL LEARNing \\ TOWARD PROBLEM SOLVING ABILITY STUDENTS ClASS VIII SMP DDI SIBATUA \\ PANGKAJENE
}

\author{
Andi Yunarni Yusri \\ Program Studi Pendidikan Matematika, STKIP Andi Matappa \\ Pangkep, Sulawesi Selatan, Indonesia \\ yunarniyusri@gmail.com
}

\begin{abstract}
Abstrak
Tujuan dari penelitian ini adalah untuk mendeskripsikan pemahaman siswa tentang notasi aljabar melalui kemampuan. Pemahaman dalam penelitian ini berarti kemampuan menerjemahkan (translasi), kemampuan menafsirkan (interpretasi), dan kemampuan untuk melakukan ekstrapolasi (ekstrapolasi). Penelitian ini merupakan penelitian kualitatif. Subyek penelitian ini adalah siswa kelas 5 di sekolah dasar, terdiri dari 2 siswa dengan kemampuan verbal tinggi yang disebut subjek verbal tinggi (SVT), 1 siswa dengan subjek verbal menengah (SVS), dan 1 siswa dengan subjek verbal rendah (SVR ). Fokus dari penelitian ini adalah untuk mendeskripsikan pemahaman siswa tentang notasi aljabar berdasarkan kemampuan verbal mereka dalam terjemahan, interpretasi, dan ekstrapolasi. Data dikumpulkan dengan melakukan wawancara berbasis uji coba dengan subyek penelitian. Data penelitian divalidasi dengan metode triangulasi, yaitu wawancara dengan menggunakan pertanyaan utama seperti pertanyaan yang tercantum dalam TPNA. Data penelitian dianalisis dengan (a) mempelajari data subjek dan membandingkan data yang diwawancarai untuk mendapatkan data yang valid, (b) melakukan reduksi data dengan membuat abstraksi, (c) mengklasifikasi dan mengidentifikasi data untuk menarik kesimpulan. Hasil penelitian menunjukkan bahwa (1) pemahaman notasi aljabar dengan subjek verbal tinggi (SVT): (a) pemahaman simbol yang termasuk dalam pemahaman translate (translasi), (b) memahami konsep simbol tapi Blum mampu membedakan antara simbol dan variabel, (c) mampu menafsirkan makna notasi aljabar (simbol dan tanda) dengan baik; (2) pemahaman notasi aljabar medium verbal subject (SVS): (a) pemahaman simbol yang termasuk dalam pemahaman translate (translasi), (b) mengenali simbol namun belum dapat membedakan simbol dan variabelnya, c) mampu menafsirkan makna notasi aljabar (simbol dan tanda) dengan baik; (3) pemahaman notasi aljabar dengan subjek verbal rendah (SVR): (a) pemahaman simbol yang termasuk dalam pemahaman translasi (translasi), (b) mengenali simbol namun belum dapat membedakan simbol dan variabelnya, c) belum bisa menafsirkan makna notasi aljabar (simbol, variabel, dan tanda) dengan baik.

Kata Kunci: Memahami Aljabar Notasi, Aljabar Notasi, Kemampuan Verbal.
\end{abstract}

\begin{abstract}
The purpose of the study is to describe the students' understanding on algebraic notation through abilities. The understanding in this study means the ability to translate (translation), the ability to interpret (interpretation), and the ability to extrapolate (extrapolation). This study is a qualitative research. The subjects of this study are 4 fifth grade students in elementary school, consisted of 2
\end{abstract}


students with high verbal ability called as high verbal subject (SVT), 1 student with medium verbal subject (SVS), and 1 student with low verbal subject (SVR). The focus of this research is to describe the students' understanding on algebraic notation based on their verbal abilities in translation, interpretation, and extrapolation. The data were collected by conducting test-based interview to the research subjects. The research data were validated by conducting triangulation method, namely interview using major questions as the questions stated in TPNA. Research data were analyzed by (a) studying the subject data and comparing interviewed data to obtain the valid one, (b) conducting data reduction by making the abstraction, (c) classifying and identifying the data to draw the conclusion. The results of the study reveals that (1) the understanding of algebraic notation of high verbal subject (SVT): (a) understanding of the symbols included in the comprehension translate (translation), (b) understand the concept of the symbol but Blum was able to distinguish between symbols and variables, (c) able to interpret the meaning of algebraic notation (symbols and signs) well; (2) the understanding of algebraic notation of medium verbal subject (SVS): (a) understanding of the symbols included in the comprehension translate (translation), (b) recognize symbols but have not been able to distinguish the symbols and variables, (c) is able to interpret the meaning of the notation algebra (symbols and signs) well; (3) the understanding of algebraic notation of low verbal subject (SVR): (a) understanding of the symbols included in the comprehension translate (translation), (b) recognize symbols but have not been able to distinguish the symbols and variables, (c) has not been able to interpret the meaning of algebraic notation (symbol, variable, and marks) well.

Keyword: Understanding the Algebraic Notation, Algebraic Notation, Verbal Ability.

\section{Pendahuluan}

Matematika merupakan ilmu universal yang mendasari perkembangan teknologi modern, sehingga mempunyai peranan penting dalam berbagai disiplin ilmu serta menjadi tolak ukur dalam kemajuan daya pikir manusia.

Disamping itu, dengan belajar matematika seseorang sedikit banyak akan terbentuk menjadi orang yang mampu berpikir logis, matematis dan objektif, yang menjadi bagian dari kepribadiannya. Oleh karena itu, dalam pendidikan formal matematika sudah diajarkan mulai dari pendidikan dasar, menengah, sampai perguruan tinggi. Melalui pendidikan di sekolah kemampuan ini kemudian dikembangkan dengan mempelajari bidang-bidang lain dari matematika, seperti aritmatika, aljabar, geometri, dan sebagainya.
Proses menuju ke arah kecakapan hidup memerlukan suatu latihan serta membutuhkan suatu proses yang disebut keterampilan proses. Melalui keterampilan proses, peserta didik akan mampu menemukan dan mengembangkan sendiri fakta dan konsep serta menumbuhkan dan mengembangkan sikap dan nilai. Seluruh tindakan dalam proses pembelajaran akan menciptakan kondisi belajar yang melibatkan siswa aktif. Rendahnya keterampilan proses dalam suatu pembelajaran akan mempengaruhi hasil belajar peserta didik di sekolah khususnya terhadap kemampuan pemecahan masalah.

Kemampuan pemecahan masalah merupakan bagian dari kurikulum matematika yang sangat penting karena dalam proses pembelajaran maupun penyelesaiannya, peserta didik dimungkinkan memperoleh pengalaman 
menggunakan pengetahuan dan keterampilan yang sudah dimiliki untuk diterapkan pada pemecahan masalah yang bersifat rutin. Pemecahan masalah merupakan kompetensi yang ditunjukkan peserta didalam memahami serta memilih strategi pemecahan untuk menyelesaikan suatu permasalahan.

Walaupun dianggap sangat penting, tapi kegiatan pemecahan masalah masih dianggap sebagai bahan yang sulit dalam matematika, baik bagi peserta didik dalam mempelajarinya maupun bagi guru dalam mengajarkannya. Demikian pula yang dialami peserta didik di SMPS DDI Sibatua Pangkajene, sebagian besar peserta didik disana merasa kesulitan jika dihadapkan dengan soal pemecahan masalah khususnya pada pembelajaran matematika. Untuk mengajarkan pemecahan masalah dengan baik, beberapa hal perlu dipertimbangkan antara lain waktu yang digunakan untuk pemecahan masalah, perencanaan pembelajaran, sumber belajar yang diperlukan, peran teknologi, dan manajemen kelas.

Menurut pengamatan penulis dan didukung data atau fakta lain melalui observasi di SMPS DDI Sibatua Pangkajene, kebanyakan guru matematika masih menggunakan metode ekspositori. Hal ini dikarenakan guru harus menyelesaikan materi yang dibebankan, sementara waktu terbatas. Pada pembelajaran dengan metode ekspositori ini banyak peserta didik yang kurang tertarik terhadap pelajaran yang disampaikan guru. Peserta didik cenderung pasif dalam menerima pelajaran, banyak peserta didik yang hanya mau belajar ketika ada tugas atau akan ulangan. Pada materi yang belum diajarkan peserta didik cenderung untuk tidak peduli, apalagi untuk membacanya. Padahal dengan membaca materi sebelum materi itu disampaikan oleh guru, akan lebih memudahkan peserta didik dalam menerima pelajaran.

Berdasarkan hasil observasi awal yang penulis lakukan di lapangan permasalahan yang masih ditemukan di SMPS DDI Sibatua Pangkajene bahwa hasil belajar untuk mata pelajaran matematika masih rendah serta kurang optimalnya kemampuan peserta didik dalam pemecahan masalah matematika. Hal ini dibuktikan dari masih banyaknya peserta didik yang memperoleh nilai rata-rata 65 , dibawah KKM (Kriteria Ketuntasan Minimal) sebesar 70 pada ujian semester. Penyebab rendahnya hasil belajar matematika peserta didik salah satunya disebabkan karena kurangnya kemampuan peserta didik dalam memahami masalah matematika, sehingga peserta didik akan kesulitan dalam memecahkan masalah matematika.

Untuk mengatasi masalah tersebut, maka diperlukan alternatif yang dalam prosesnya menggunakan pendekatan yang tidak berpusat pada pendidik saja (Teacher Centered) dimana dalam proses belajar mengajar matematika guru hendaknya memberikan kesempatan yang cukup kepada peserta didik untuk dapat mengalami sendiri apa yang dipelajari dan 
berorientasi pada kompetensi peserta didik khususnya kemampuan pemecahan masalah matematika.

Matematika adalah suatu yang berkenaan dengan ide-ide atau konsepkonsep abstrak yang tersusun secara hirarkis dan penalaran deduktif. Menurut R. Soedjadi \& Masriyah, (dalam Amin Suyitno, 2008: 52), Ciri-ciri dari matematika adalah:

1. Matematika memiliki objek kajian yang abstrak

2. Matematika mendasarkan diri pada kesepakatan-kesepakatan

3. Matematika sepenuhnya menggunakan pola pikir deduktif

4. Matematika dijiwai dengan kebenaran konsisten.

Pembelajaran matematika sekolah pada dasarnya harus berorientasi pada upaya menciptakan iklim dan pelayanan terhadap kemampuan, potensi, minat, bakat, dan kebutuhan peserta didik yang beragam, sehingga terjadi interaksi secara optimal antara guru dengan pesertadidik serta antara peserta didik dengan peserta didik, sebab guru disini mempunyai peran dan tanggung jawab atas penyelenggaraan pembelajaran di sekolah (di dalam kelas maupun di luar kelas). Selain itu, perubahan yang perlu direnovasi salah satunya adalah pada orientasi pembelajaran yang semula terpusat pada guru (Teacher Centered) beralih berpusat pada murid (Student Centered) metodologi yang semula lebih dominan ekpositori berganti ke partisipasi dan pendekatan yang semula lebih banyak bersifat tekstual berubah menjadi kontekstual.

Menurut J. Bruner (dalam Hidayat, 2009: 8), "belajar merupakan suatu proses aktif yang memungkinkan manusia untuk menemukan hal-hal baru di luar informasi yang diberikan kepada dirinya". Dalam proses belajar Bruner mementingkan partisipasi aktif dari tiap peserta didik dan mengenal dengan baik adanya perbedaan kemampuan, untuk meningkatkan proses belajar perlu adanya lingkungan dimana peserta didik dapat melakukan eksplorasi, penemuan-penemuan baru yang belum dikenal atau pengertian-pengertian yang mirip dengan yang sudah diketahui, hubungan-hubungan dan hambatan yang dihayati oleh peserta didik secara berbeda-beda.

Proses belajar mengajar terjadi secara optimal jika pengetahuan tersebut dipelajari dalam tahap-tahap sebagai berikut:

\section{Tahap Enaktif}

Suatu tahap pembelajaran dimana pengetahuan dipelajari secara aktif dengan menggunakan benda-benda konkret atau situasi yang nyata.

2. Tahap Ikonik

Suatu tahap pembelajaran dimana pengetahuan dipresentasikan (diwujudkan) dalam bentuk bayangan (visual imagery), gambar atau diagram yang menggambarkan kegiatan konkret atau situasi konkret yang terdapat pada tahap enaktif.

3. Tahap Simbolik 
Suatu tahap pembelajaran dimana pengetahuan dipresentasikan dalam bentuk simbol abstrak, baik simbol verbal (misalkan huruf, kata atau kalimat), lambang matematika, maupun lambang abstrak lainnya.

Teori makna (meaning Theory dari ausubel (Brownell dan chazal) mengemukakan pentingnya pembelajaran yang bermakna. Kebermaknaan pembelajaran akan membuat kegiatan belajar lebih menarik, lebih manfaat, dan lebih menantang, sehingga konsep dan prosedur materi yang disampaikan akan lebih mudah dipahami dan lebih tahan lama diingat oleh peserta didik. Salah satu wujud kebermaknaan yang dikaitkan pendekatan keterampilan proses dengan pembelajaran matematika, peserta didik dilatih keterampilan-keterampilan proses dalam pemecahan masalah, antara lain dengan mengajukan pertanyaan, menjawab pertanyaan, menyampaikan pendapat, mendengarkan secara aktif dan sebagainya, sehingga kebermaknaan pembelajaran lebih tercapai.

Menurut Gordon (Wina Sanjaya 2010: 152) menjelaskan bahwa "keterampilan (skill) adalah sesuatu yang dimiliki oleh individu untuk melakukan tugas yang dibebankan". Artinya bahwa individu mempunyai karakter yang berbeda, sehingga pada saat sedang belajar ada yang cepat memahami pelajaran yang diberikan oleh guru dan ada pula yang lambat memahaminya bahkan tidak memahami sedikit pun terhadap materi yang diberikan oleh guru.
Pendekatan keterampilan proses (dalam Oemar Hamalik, 2001) merupakan pendekatan pembelajaran yang menekankan pada proses belajar, aktivitas dan kreativitas siswa dalam memperoleh pengetahuan, keterampilan, nilai, dan sikap serta menerapkannya dalam kehidupan sehari-hari. Dalam hal ini siswa diberi kesempatan untuk terlibat secara aktif dalam proses menemukan dan memahami konsep-konsep atau prinsipprinsip matematika yang dipelajari. Pendekatan keterampilan proses sebagai pendekatan yang menekankan pada penumbuhan dan pengembangan sejumlah keterampilan tertentu pada diri peserta didik agar mampu memproses informasi sehingga ditemukan hal-hal yang baru yang bermanfaat baik berupa fakta, konsep, maupun pengembangan sikap dan nilai.

Proses pembelajaran dengan pendekatan ini dimulai dari obyek nyata atau obyek yang sebenarnya dengan menggunakan pengalaman langsung, sehingga peserta didik di arahkan untuk memahami sendiri konsep-konsep matematika yang sedang dipelajarinya. Peserta didik juga diajak, dilatih, dan dibiasakan melakukan observasi langsung dan membuat kesimpulan sendiri

Adapun menurut Dimyati dan Mujiono (2009: 159) dikemukakan bahwa "pendekatan keterampilan proses bukanlah tindakan instruksional yang berada diluar kemampuan peserta didik, melainkan yang bersumber dari kemampuan-kemampuan mendasar yang 
pada prinsipnya telah ada dalam diri peserta didik". Pendekatan keterampilan proses dimaksudkan untuk mengembangkan kemampuankemampuan yang dimiliki oleh peserta didik yaitu sebagai berikut:

a. Pendekatan keterampilan proses memberikan kepada peserta didik pengertian yang tepat tentang hakikat ilmu pengetahuan. Peserta dapat mengalami rangsangan ilmu pengetahuan dan dapat lebih baik mengerti fakta dan konsep ilmu pengetahuan.

b. Mengajar dengan keterampilan proses berarti member kesempatan kepada peserta didik bekerja dengan ilmu pengetahuan, tidak sekedar menceritakan atau mendengarkan cerita tentang ilmu pengetahuan. Disisi lain, peserta didik merasa senang karena mereka aktif dan tidak menjadi pembelajar yang pasif.

c. Menggunakan keterampilan proses untuk mengajar ilmu pengetahuan, membuat peserta didik belajar proses dan produk ilmu pengetahuan sekaligus.

Moh. Uzer Usman (2008: 43), mengemukakan penjabaran keterampilan proses dalam bentuk kemampuan adalah sebagai berikut:

Tabel 1.

Penjabaran jenis-jenis keterampilan proses

\begin{tabular}{lll}
\hline No. & Keterampilan & \multicolumn{1}{c}{ Kemampuan } \\
\hline 1 & Mengamati & Melihat, \\
& & mendengarkan, \\
& & merasa, meraba, \\
& & membaur, mencicipi, \\
& & mengecap,
\end{tabular}

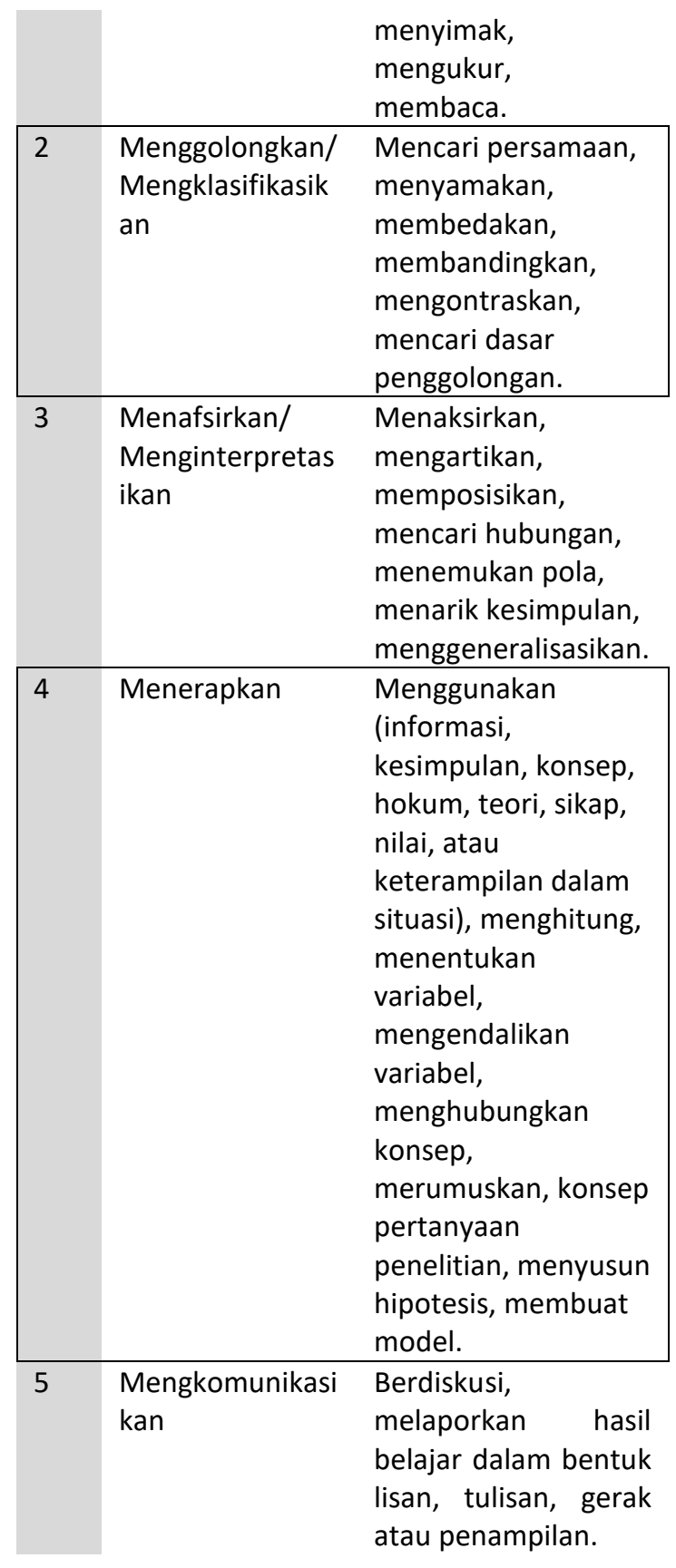

Polya (dalam Ani Minarni, 2014) mengartikan pemecahan masalah sebagai suatu usaha mencari jalan keluar dari suatu tujuan yang tidak begitu mudah segera dapat dicapai. Sedangkan Siswono (2008: 35), menjelaskan bahwa "pemecahan masalah adalah suatu proses atau upaya individu untuk merespon atau 
mengatasi halangan atau kendala ketika suatu jawaban atau metode jawaban belum tampak jelas". Dari pengertian pemecahan masalah yang dikemukakan di atas dapat disimpulkan bahwa diperolehnya solusi suatu masalah menjadi syarat bagi proses pemecahan masalah dikatakan berhasil. Pemecahan masalah merupakan proses penerimaan masalah sebagai tantangan untuk menyelesaikan masalah tersebut. Mengajarkan pemecahan masalah kepada peserta didik merupakan kegiatan dari seorang guru dimana guru itu membangkitkan peserta didiknya agar menerima dan merespon pertanyaan-pertanyaan yang digunakan oleh nya dan kemudian ia membimbing peserta didiknya untuk sampai kepada penyelesaian masalah.

Suatu pertanyaan akan menjadi masalah bagi seorang peserta didik pada suatu saat, tetapi bukan masalah bagi peserta didik tersebut untuk soal berikutnya bila peserta didik tersebut telah mengetahui cara atau prosedur untuk menyelesaikan masalah tersebut. Pertanyaan akan menjadi masalah bagi peserta didik jika:

1. Pertanyaan yang dihadapkan pada seorang peserta didik haruslah dapat dimengerti oleh peserta didik tersebut, namun pertanyaan itu harus merupakan tantangan baginya untuk menjawabnya.

2. Pertanyaan tersebut tidak dapat dijawab dengan prosedur rutin yang telah diketahui peserta didik. Oleh karena itu faktor waktu jangan dipandang sebagai hal yang esensial.

Dalam matematika, pertanyaan yang dihadapkan kepada peserta didik biasa disebut soal. Soal matematika dibedakan menjadi dua bagian sebagai berikut:

1. Latihan yang diberikan pada waktu belajar matematika adalah bersifat terlatih agar terampil atau sebagai aplikasi dari pengertian yang baru saja diajarkan.

2. Masalah tidak seperti halnya latihan tadi, menghendaki peserta didik untuk menggunakan sintesis atau analisis. Untuk menyelesaikan suatu masalah, peserta didik tersebut harus mampu menguasai hal-hal yang telah dipelajari sebelumnya yaitu mengenal pengetahuan, keterampilandan pemahaman, tetapi dalam hal ini ia menggunakan pada situasi baru.

Adapun syarat suatu soal menjadi soal pemecahan masalah adalah:

1. Peserta didik mempunyai pengetahuan prasyarat untuk mengerjakan soal tersebut.

2. Diperkirakan peserta didik mampu menyelesaikan soal tersebut.

3. Peserta didik belum tahu algoritma atau cara menyelesaikan soal tersebut.

4. Peserta didik mau dan berkehendak untuk menyelesaikan soal tersebut.

Ketika syarat terpenuhi maka, soal tersebut dikatakan soal pemecahan masalah yang selanjutnya dapat diselesaikan dengan langkah-langkah 
tertentu. Mengenai langkah-langkah dalam pemecahan masalah adalah sebagai berikut:

1. Memahami masalah: memahami dan mengidentifikasi apa fakta/informasi yang diberikan, apa yang ditanyakan, diminta untuk dicari/dibuktikan.

2. Merencanakan pemecahan masalah: misalnya menggambarkan masalah dalam bentuk diagram maupun tabel, memilih dan menggunakan pengetahuan aljabar yang diketahui dan konsep yang relevan untuk membentuk model atau kalimat matematika.

3. Melaksanakan rencana pemecahan masalah: melakukan operasi hitung secara benar dalam menerapkan strategi untuk mendapatkan solusi dari masalah.

4. Menafsirkan atau mengecek hasilnya: memperkirakan dan memeriksa kebenaran jawaban, masuk akalnya jawaban, dan apakah memberikan pemecahan terhadap masalah tersebut.

\section{Metode}

Penelitian ini dilaksanakan di SMP DDI Sibatua Pangkajene. Dalam penelitian ini menggunakan pendekatan kuantitatif. Jenis penelitian ini adalah penelitian praeksperimen. Metode yang digunakan dalam penelitian ini adalah metode penelitian eksperimen yang dilaksanakan pada satu kelompok saja yang dinamakan kelompok eksperimen tanpa ada kelompok pembanding atau kelompok kontrol.

Dalam penelitian ini desain yang digunakan adalah desain "one-group pretest-posttest design". Dalam desain ini menggunakan satu kelompok subjek. pretest $\left(\mathrm{O}_{1}\right)$ diberikan sebelum siswa mendapat perlakuan berupa penerapan pendekatan keterampilan proses, kemudian setelah mengadakan pretest peneliti memberikan perlakuan (X) kepada siswa. Setelah selesai memberikan perlakuan, peneliti memberikan posttest $\left(\mathrm{O}_{2}\right)$. Desain ini dapat digambarkan sebagai berikut:

Tabel 2.

Desain penelitian one-group pretest-posttest design

\begin{tabular}{lcc}
\hline Pretest & Treatment & Posttest \\
\hline $\mathrm{O}_{1}$ & $\mathrm{X}$ & $\mathrm{O}_{2}$
\end{tabular}

(Sumber: Sugiyono, 2013)

Keterangan:

X Perlakuan (pembelajaran dengan pendekatan keterampilan proses)

$\mathrm{O}_{1}$ Pemberian tes yang dikenakan pada kelompok sebelum diberi perlakuan

$\mathrm{O}_{2}$ Pemberian tes yang dikenakan pada kelompok setelah diberi perlakuan

Definisi operasional variabel pada penelitian ini adalah: (1) Pembelajaran dengan Pendekatan Keterampilan Proses dalam lingkup materi lingkaran yang dilaksanakan di kelas VIII SMP DDI Sibatua Pangkajene dengan menggunakan pendekatan keterampilan proses yang dimulai dari obyek nyata atau obyek yang sebenarnya dengan menggunakan pengalaman langsung sehingga peserta didik diharapkan terjun dalam kegiatan belajar mengajar yang lebih realistis, 
dimana anak diajak, dilatih, dan dibiasakan melakukan observasi langsung dan membuat kesimpulan sendiri,

Kemampuan Pemecahan Masalah, Skor yang diperoleh peserta didik kelas VIII SMP DDI Sibatua Pangkajene setelah mengikuti proses belajar mengajar menggunakan pendekatan keterampilan proses yang diperoleh dengan tes hasil belajar matematika pada ranah kognitif dalam lingkup materi lingkaran.

Menurut Sukmadinata (2006: 250) mengemukakan bahwa populasi adalah kelompok besar dan wilayah yang menjadi lingkup penelitian tertentu yang ditetapkan oleh peneliti untuk dipelajari dan kemudian ditarik kesimpulannya. Populasi dalam penelitian ini adalah seluruh peserta didik kelas VIII SMPS DDI Sibatua Pangkajene yang terbagi ke dalam 1 kelas yaitu kelas VIII dengan jumlah 24 orang.

Menurut Sugiyono (2013: 66), sampel adalah sebagian dari jumlah dan karakteristik yang dimiliki oleh populasi tersebut. Sampel dalam penelitian ini ditentukan dengan teknik nonrandom sampling, yaitu teknik penentuan sampel bila semua anggota populasi digunakan sebagai sampel. Hal ini dilakukan bila jumlah populasi relatif kecil, kurang dari 30 orang. Istilah dari sampel ini adalah sampel jenuh (sensus), dimana semua anggota populasi dijadikan sampel dengan jumlah sampel 24 orang.

\section{Hasil dan Pembahasan}

\section{A. Analisis Data Deskriptif}

Data hasil penelitian terhadap kemampuan pemecahan masalah peserta didik kelas VIII SMP DDI Sibatua Pangkajene pada pokok bahasan lingkaran sebelum mengikuti pembelajaran pendekatan keterampilan proses, dan kemudian peneliti merangkumnya seperti yang diperlihatkan pada tabel 3 berikut ini:

Tabel 3.

Deskripsi Skor Kemampuan Pemecahan Masalah Peserta Didik Sebelum Diajar Menggunakan Pendekatan Keterampilan Proses

\begin{tabular}{|c|c|c|c|}
\hline Interval Skor & Kategori & Frekuensi & $\begin{array}{c}\text { Persentase } \\
(\%)\end{array}$ \\
\hline$<45$ & $\begin{array}{l}\text { Sangat } \\
\text { Kurang }\end{array}$ & 7 & 29.17 \\
\hline $45-54$ & Kurang & 10 & 41.66 \\
\hline $55-67$ & Cukup & 7 & 29.17 \\
\hline $68-79$ & Baik & 0 & 0 \\
\hline $80-100$ & $\begin{array}{c}\text { Sangat } \\
\text { Baik }\end{array}$ & 0 & 0 \\
\hline \multicolumn{2}{|c|}{ Total } & 24 & 100.00 \\
\hline
\end{tabular}

(Sumber : Hasil analisis data)

Tabel 4.

Deskripsi Ketuntasan Skor Kemampuan Pemecahan masalah Peserta Didik

\begin{tabular}{cccc|}
\hline Skor & Kategori & Frekuensi & $\begin{array}{c}\text { Persentase } \\
\text { (\%) }\end{array}$ \\
\hline $0 \leq$ Nilai $<70$ & $\begin{array}{c}\text { Tidak } \\
\text { Tuntas }\end{array}$ & 24 & 100.00 \\
\hline $\begin{array}{c}70 \leq \text { Nilai } \leq \\
100\end{array}$ & Tuntas & 0 & 0 \\
\hline $\begin{array}{c}\text { Jumlah } \\
\text { (Sumber : Hasil analisis data) }\end{array}$ & 24 & 100.00 \\
\hline \multicolumn{4}{c}{ Tabel 5. } \\
Peserta Didik Sesudah Diajar Menggunakan \\
Pendekatan Keterampilan Proses \\
\hline $\begin{array}{c}\text { Interval Skor } \\
\text { Kategori }\end{array}$ & Frekuensi & $\begin{array}{c}\text { Persentase } \\
\text { (\%) }\end{array}$ \\
\hline$<45$ & $\begin{array}{c}\text { Sangat } \\
\text { Kurang }\end{array}$ & 0 & 0 \\
\hline $45-54$ & Kurang & 0 & 0 \\
\hline
\end{tabular}




\begin{tabular}{|cccc|}
\hline $55-67$ & Cukup & 0 & 0 \\
\hline $68-79$ & Baik & 8 & 33.33 \\
\hline $80-100$ & $\begin{array}{c}\text { Sangat } \\
\text { Baik }\end{array}$ & 16 & 66.67 \\
\hline Total & & $\mathbf{2 4}$ & 100 \\
\hline
\end{tabular}

(Sumber : Hasil analisis data)

Tabel 6.

Deskripsi Ketuntasan Skor Kemampuan Pemecahan masalah Peserta Didik

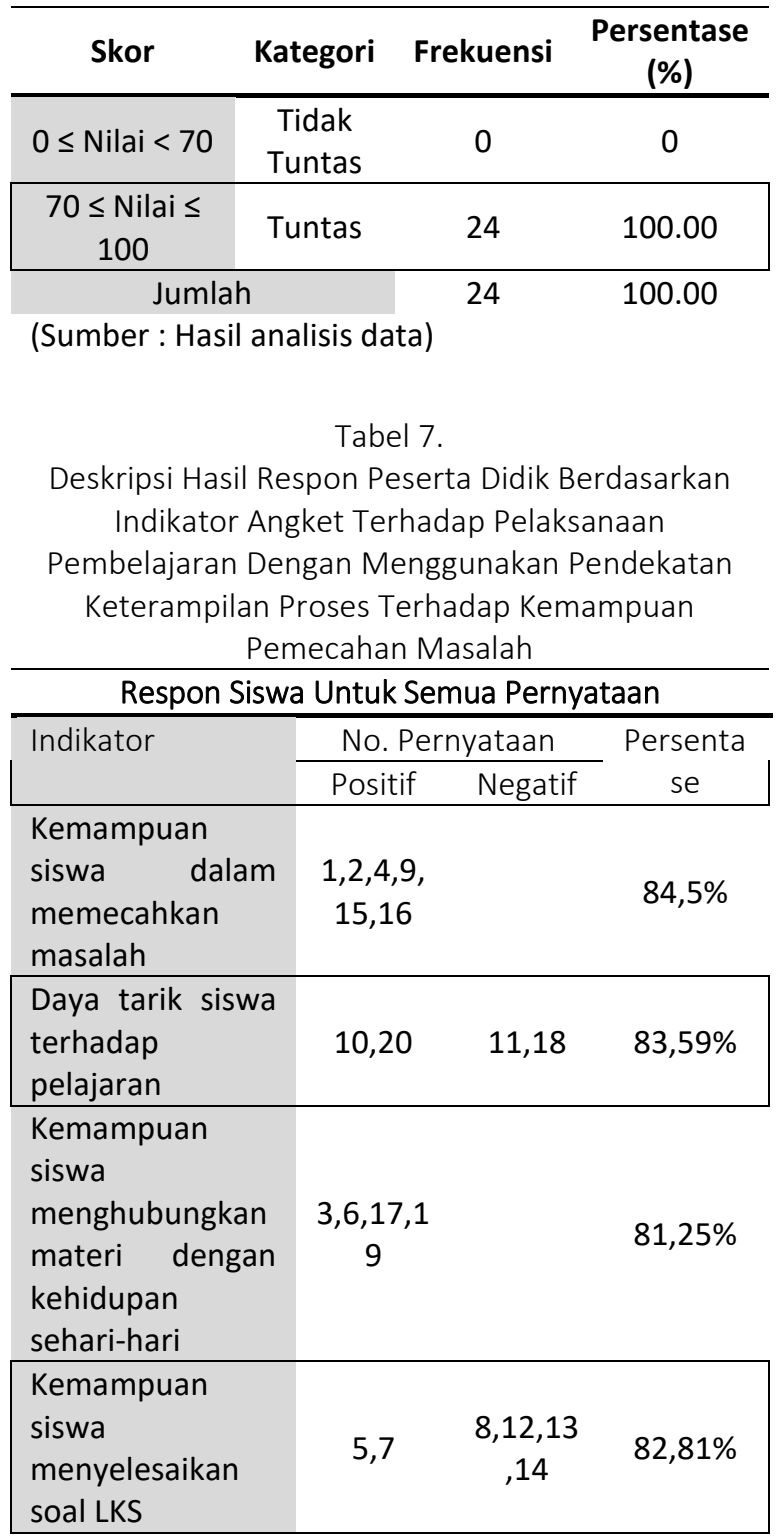

\section{B. Pembahasan}

Berdasarkan pada hasil penelitian yang telah diuraikan, maka pada bagian pembahasan hasil penelitian meliputi pembahasan hasil analisis deskriptif dan pembahasan hasil analisis inferensial serta data respon peserta didik.

Pembahasan hasil analisis deskriptif terkait hasil skor kemampuan pemecahan masalah peserta didik. Hasil analisis data skor kemampuan pemecahan masalah peserta didik pada pokok bahasan lingkaran, sebelum diajar menggunakan pendekatan keterampilan proses berada pada rata-rata 46.71. Sedangkan sesudah diajar menggunakan pendekatan keterampilan proses berada pada rata-rata 80.08 dengan ketuntasan minimal 70 . Dilihat dari kategori ketuntasan hasil belajar peserta didik kelas VIII SMP DDI Sibatua Pangkajene sebelum penerapan pendekatan keterampilan proses belum memenuhi kriteria ketuntasan karena terdapat 24 peserta didik (100\%) yang tidak tuntas. Sedangkan sesudah penerapan pendekatan keterampilan proses tidak terdapat peserta didik (0\%) yang tidak tuntas dan 24 peserta didik (100\%) yang tuntas, sehingga dapat dikatakan bahwa pada pembelajaran sesudah menggunakan pendekatan keterampilan proses peserta didik kelas VIII SMP DDI Sibatua Pangkajene memenuhi kriteria ketuntasan klasikal yakni $75 \%$.

Adapun berdasarkan hasil analisis ratarata respon peserta didik terhadap pelaksanaan pembelajaran dengan menggunakan pendekatan keterampilan proses menunjukkan bahwa rata-rata persentase kemampuan siswa dalam memecahkan masalah yaitu sebesar 
$84,5 \%$, daya tarik siswa terhadap pelajaran sebesar 83,59\%, kemampuan siswa menghubungkan materi dengan kehidupan sehari-hari sebesar $81,25 \%$, dan kemampuan siswa menyelesaikan soal LKS sebesar $82,81 \%$.

Dari hasil penelitian yang diperoleh menunjukkan bahwa pembelajaran dengan pendekatan keterampilan proses dapat membantu peserta didik untuk meningkatkan kemampuan pemecahan masalah peserta didik hal ini sejalan dengan tujuan pendekatan keterampilan proses, diantaranya memberikan motivasi belajar kepada siswa karena dalam keterampilan proses siswa dipacu untuk senantiasa berpartisipasi aktif dalam belajar, untuk lebih memperdalam konsep pengertian dan fakta yang dipelajari siswa karena pada hakikatnya siswa sendirilah yang mencari dan menemukan konsep tersebut, untuk mengembangkan pengetahuan atau teori dengan kenyataan hidup dalam masyarakat sehingga antara teori dan kenyataan hidup akan serasi, sebagai persiapan dan latihan dalam menghadapi hidup di dalam masyarakat karena siswa telah dilatih untuk berpikir logis dalam memecahkan masalah, dan mampu mengembangkan sikap percaya diri, bertanggung jawab dan rasa kesetiakawanan sosial dalam menghadapi berbagai masalah. Pendekatan keterampilan proses juga dapat meningkatkan potensi intelektual peserta didik. Karena peserta didik diberi kesempatan untuk mencari dan menemukan sendiri jawaban dari permasalahan yang diberikan dengan pengamatan dan pengalaman sendiri. Dari hasil penelitian ini dapat disimpulkan bahwa pembelajaran dengan menggunakan pendekatan keterampilan proses dapat meningkatkan kemampuan pemecahan masalah peserta didik kelas VIII SMP DDI Sibatua Pangkajene.

\section{Penutup}

Penutup ditulis untuk mengarahkan pembaca mendapatkan hal-hal penting yang tidak dangkal dan sempit. Penutup terdisi dari dua bagian, kesimpulan dan saran. Kesimpulan menyajikan ringkasan dari uraian mengenai hasil dan pembahasan, mengacu pada tujuan penelitian. Berdasarkan kedua hal tersebut dikembangkan pokok-pokok pikiran baru yang merupakan esensi dari temuan penelitian.

Berdasarkan hasil analisis data dan pembahasan hasil penelitian yang dilakukan terhadap peserta didik kelas VIII SMP DDI Sibatua Pangkajene, maka dapat disimpulkan bahwa:

Kemampuan pemecahan masalah peserta didik kelas VIII SMP DDI Sibatua Pangkajene pada pokok bahasan lingkaran sebelum penerapan pendekatan keterampilan proses berada pada kategori kurang dengan persentase $46,71 \%$.

Kemampuan pemecahan masalah peserta didik kelas VIII SMP DDI Sibatua Pangkajene pada pokok bahasan lingkaran sesudah penerapan pendekatan keterampilan proses berada pada kategori sangat baik dengan persentase $80,08 \%$. 
Terdapat perbedaan yang signifikan terhadap kemampuan pemecahan masalah peserta didik kelas VIII SMP DDI Sibatua Pangkajene sebelum dan sesudah penerapan pendekatan keterampilan proses pada pokok bahasan lingkaran.

\section{DAFTAR PUStaka}

Amin Suyitno. (2008). Dasar-dasar Pembelajaran Matematika I. Semarang: UNNES.

Ani Minarni. (2014). Pengaruh Pembelajaran Berbasis Masalah Terhadap Kemampuan Pemecahan Masalah Terhadap Kemampuan Matematika Dan Keterampilan Sosial Siswa. Jurnal Pendidikan Matematika PARADIKA, Vol 6 nomor 2 hal.162 (diakses pada tanggal 28 April 2016).

Dimyati \& Mujiono. (2009). Belajar dan Pembelajaran. Jakarta: Rineka Cipta.

Hidayat. (2009). Diktat Mata kuliah Teori Pembelajaran Matematika. Semarang. Inayatul Hidayah. (2011). Pengaruh Pembelajaran Matematika Dengan Pendekatan Keterampilan Proses

Terhadap Hasil Belajar Peserta Didik Kelas VII MTs Nurul Huda. Semarang: Skripsi.

Kasmadi. (2014). Panduan Modern Penelitian Kuantitatif. Bandung: Alfabeta.

Moh. Uzer Usman. (2008). Menjadi Guru Profesional. Bandung: Remaja Rosdakarya.

Nanang Budi Nugroho. (2014). Pengembangan Rpp Dan Lks Berbasis Problem Based
Learning Pada Materi Himpunan Untuk Siswa Smp Kelas VII, Skripsi, Universitas Negeri Yogyakarta, Yogyakarta.

Oemar Hamalik. (2001). Proses Belajar Mengajar. Jakarta: Bumi Aksara.

Riyanto. (2002). Paradigma Baru Pembelajaran. Jakarta: Kencana.

Siswono. (2008). Model Pembelajaran Matematika Berbasis Pengajuan dan Pemecahan Masalah Untuk Meningkatkan Kemampuan Berpikir Kreatif. Surabaya: UNESA University Press.

Sugiyono. (2013). Metode Penelitian Pendidikan (Pendekatan Kuantitatif, Kualitatif, dan R\&D). Bandung: Alfabeta.

Suhana. (2015). Penerapan Model Pembelajaran Inkuiri Terhadap Pemahaman Konsep Matematika Peserta Didik Pada Pokok Bahasan Kubus dan Balok Kelas VIII SMP Negeri 3 Ma'rang Kabupaten Pangkep. Skripsi, Tidak diterbitkan, STKIP Pangkep.

Sukmadinata. (2006). Metode Penelitian Pendidikan. Bandung: Remaja Rosdakarya.

Walker. (1996). Paradigma Baru Pembelajaran. Jakarta: Kencana. Wina Sanjaya. (2010). Penelitian Tindakan Kelas. Jakarta: Pranada Media Group. 